\title{
FINANCIAL DISTRESS AND MANAGERIAL TURNOVER: THE CASE OF THE REPUBLIC OF SERBIA
}

\section{Dragana Radjen, Nemanja Stanisic ${ }^{*}$}

\begin{abstract}
This study examines the influence of financial distress on top management turnover in the Republic of Serbia over the period January 2009-June 2015. Using a sample of 86 large and medium-sized privately owned companies that adopted a reorganisation plan in bankruptcy, we found out that top management was changed in 33 companies. A logistic regression provides evidence that probability of top management turnover is significantly correlated with the company's size (positive correlation) and the ownership concentration (negative correlation). The influence of the company's financial performance, applied bankruptcy proceedings and debt monitoring of top management turnover was deemed to be statistically insignificant (at $5 \%$ and $10 \%$ significance level). Obtained results provide the proof that corporate governance mechanisms in distressed Serbian companies are not efficient.
\end{abstract}

Keywords: bankruptcy, distress, top management turnover

JEL Classification: G33, G34

\section{Introduction}

Despite the privatisation process, which commenced in 1991, the share of the private sector in the Serbian economy is modest and state-owned entities (SOEs) still play a significant role in key industries. The majority of Serbian companies in the private sector are characterised by a lack of managerial skills, low financial accountability, insufficient corporate transparency, and limited access to external finances. At the same time, SOEs are burdened with political interference in the company's management, technical and organisational inefficiencies. In an economy such as that of Serbia, with poor protection for minority shareholders, an undeveloped capital market, massive government interference and uncertain business conditions, managers are subject to less pressure from a capital and managerial labour market. In these economies, concentrated ownership provides the maximum rate of return for shareholders and efficient management control. However, when a company faces financial distress, it is not clear who disciplines the company's management. The objective of the research is to determine factors that influence top management turnover in distressed Serbian companies. The first study in this area of concern for the Republic of Serbia was conducted by Radjen (2015), who examined the influence of financial distress on top management in a sample of 39 large- and medium-sized companies that adopted

* Dragana Radjen, Singidunum University, Faculty of Business, Belgrade, Serbia (dragana.radjen1@gmail.com);

Nemanja Stanisic, Singidunum University, Faculty of Business, Belgrade, Serbia (nstanisic@singidunum.ac.rs). 
the reorganisation plan from 2009 to 2014. The research indicated the presence of a strong negative relationship between a company's liquidity and the probability of top management turnover. In order to provide detailed analysis regarding the influence of financial distress on corporate governance mechanisms, this study extends the research period, increases the number of analysed companies, and explores the influence of more variables.

Despite the fact that our research results are dependent on the Serbian institutional and legal environment, this study can help other researchers to obtain a better understanding of changes that are essential for the effectiveness of the corporate governance system in Southeast Europe. Improvements of corporate governance practice and structural reforms of the judicial system are major challenges for the Republic of Serbia in the EU integration process, and our findings can help the regulators to adopt appropriate reforms. Furthermore, the corporate governance structure of reorganised companies influences its post-bankruptcy success. Keeping in mind that, at the end of the fourth quarter of 2015, the NPL portfolio accounted for $21.6 \%$ of the total banking portfolio in the Republic of Serbia, out of which $26.5 \%$ refers to the corporate sector in bankruptcy, this article is also of special interest to banks as the main creditors of the Serbian corporate sector.

In order to understand the obtained results, we will briefly explain the major characteristics of the legal and institutional framework in the Republic of Serbia.

\section{The Legal and Institutional Environment}

Serbian bankruptcy law introduced bankruptcy reorganisation rules in 2004. A reorganisation plan can be filed along with an insolvency petition (which is called a pre-pack reorganisation plan) or within 90 days after opening the bankruptcy (which is called a reorganisation plan). In both cases (pre-packaged bankruptcy and regular bankruptcy proceedings), the company must meet the insolvency criteria: It does not respond to its pecuniary commitments for a period of 45 days, it ceases all payments during a period of 30 days, or faces imminent illiquidity. Only a debtor (i.e. a company's management team) has the capacity to file a pre-pack reorganisation plan. In regular bankruptcy proceedings, the debtor, insolvency administrators, creditors and debtor's owners can file the reorganisation plan. In the case of pre-packaged bankruptcy, the company's owners and managers still retain control over the company's business during the bankruptcy period. However, in nearly all reorganisation cases in which a debtor files a bankruptcy petition along with a pre-packed reorganisation plan, the court appoints an insolvency administrator to take care of the legality of the bankruptcy proceedings and issues approvals to the company's managers for specific transactions (i.e. new investments, sale of the assets, etc.). In the case of regular bankruptcy proceedings, the insolvency administrator has the general authority to manage the company's business.

The major creditors of distressed Serbian companies are banks and the state. In the past, banks were hiding problems related to non-performing loans (NPL) portfolios from regulatory authorities. For the same reason, they were not interested in liquidating bad loans, so they applied a soft-loan strategy. Recently, banks have started to take a more active role in bankruptcy proceedings and the monitoring of distressed companies. The influence 
is achieved through the creditors' committee, which is established during the regular bankruptcy proceedings, and after the reorganisation plan has been adopted. The state predominately supports the reorganisation plans of distressed companies in order to avoid the downsizing of the entire economy. Moreover, the state-owned companies (and banks) transfer the burden of bad debts to the state, and this behaviour encourages their passive role in the bankruptcies of distressed companies.

With regards to the control of Serbian companies, the Law on Companies envisages a one- or two-tier corporate governance structure. In the one-tier system, the mandatory corporate bodies are the shareholders' assembly and one or more directors. In the case of the two-tier system, the mandatory corporate bodies are the shareholders' assembly, the supervisory board, one or more directors, and also an executive board, in the case of a joint-stock company. Due to the poor protection of minority shareholders and an undeveloped capital market, most Serbian companies have controlling blockholders who possess ownership shares of $50 \%$ or more. Ownership concentration ensures effective control of top managers; however, it enables controlling shareholders to extract the private benefits of control at the expense of minority shareholders and other company's investors.

The remainder of this paper proceeds as follows: Part 3 presents a literature review. Part 4 describes the sample and data sources, dating convention, specification of the research model, hypotheses and variables that we used in order to investigate the influence of financial distress on top management, and the descriptive statistics. Part 5 describes the logit models that were used in the research, and discusses our empirical evidence and limitations of the study. Finally, in Part 6, we draw overall conclusions.

\section{Theoretical Framework}

One way to measure the effectiveness of the national corporate governance system is through top management turnover (Volpin, 2002; Firth et al., 2006). Literature about distressed companies in the United States and Germany confirms a negative relationship between corporate performance and top management turnover. In these markets, top management turnover rates range from 19\% to 91\% (Gilson, 1989, 1990; LoPucki and Whitford, 1993a, 1993b; Hotchkiss, 1995; Franks and Mayer, 2001; Jostarndt and Sautner, 2008; Eckbo et al., 2012; among others). Franks et al. (2001) identify five sources of top management turnover in distressed companies in market economies (the United Kingdom and the United States): blockholders, take-over bidders, outside directors, and investors and creditors in the case of bankrupt companies. Jostarndt and Sautner (2008) document that a forced top management turnover in a distressed German company is initiated by banks and outside investors, rather than the company's owners. The negative relationship between top management turnover and a company's performance, in the case of Chinese listed companies, is confirmed by Firth et al. (2006) and Hu and Leung (2012). These authors determine that outside directors and intensive state control are the main corporate governance mechanisms in China. For Central and Eastern Europe (CEE) economies, Eriksson (2005) also documents the presence of an inverse relationship between a company's performance and top management turnover in Czech and Slovak companies. 


\section{Methodology and Descriptive Statistics}

\subsection{Sample and data source}

We began our research with the analysis of 89 large- and medium-sized privately owned nonfinancial businesses that were organised as joint-stock or limited liability companies, and that adopted a reorganisation plan between January 1, 2009 and June 30, 2015. Our investigation started in 2009 due to the fact that reorganisation plans for the majority of reorganised companies were not publicly available prior to that year. The information concerning privately owned companies that have adopted a reorganisation plan in the Republic of Serbia was obtained from the Bankruptcy Supervision Agency, as well as from 16 Commercial Courts. A company is considered to be privately owned when the state owns less than $50 \%$ of the company's shares in the bankruptcy filing year; otherwise, it is considered to be state-owned. The 50\% ownership gives the company's owner sufficient control over its decision-making processes. We excluded from our sample state-owned companies because the placement of managers in these companies is highly politicised. In our research we also omitted financial institutions, which are subject to special bankruptcy regulations. Information concerning the corporate governance structure, reorganisation plans and financial statements of distressed companies were collected from the Serbian Business Register Agency, the Portal of the Serbian Commercial Courts, the Belgrade Stock Exchange, bankruptcy judges, the companies' official websites, and the Boniteti.rs and Poslovna.rs websites. In the research, we excluded 3 companies for which the reorganisation plans were not available.

Our final sample consists of 86 medium- and large-sized private companies in financial distress, organised as joint-stock (33 companies $-38.4 \%$ ) or limited liability (53 companies - 61.6\%) companies. A company is classified as financially distressed if, in any two consecutive years, the company's earnings before interest and taxes (EBIT) are less than its interest expenses. Jostarndt and Sautner (2008) used the same definition of financial distress in similar research. This definition of financial distress is applicable to all types of companies and it does not impose restrictions with respect to the company's capital structure (Jostarndt and Sautner, 2008).

In the final sample, 49 companies applied a one-tier corporate governance structure (i.e. top management structure consists of one or more directors), while 37 companies had a two-tier corporate governance structure (i.e. top management structure consists of one or more directors, the supervisory board, and executive board). During the observed period, the ownership structure changed for 19 companies, while the top management structure changed for 33 companies. Table 1 contains the time-series distribution of top management turnover during the observed periods. Detailed information of the top management structure was not available for the majority of the companies from our sample. Accordingly, we were not able to determine the top management turnover rate during the observed period. 
Table 1 | Top Management Turnover during Sample Periods

\begin{tabular}{|l|c|c|}
\hline Period & Number & Percentage (\%) \\
\hline T0 & 14 & 42.42 \\
\hline T+1 & 13 & 39.40 \\
\hline T0 and T+1 & 6 & 18.18 \\
\hline Total & 33 & 100.00 \\
\hline
\end{tabular}

\subsection{Dating convention}

In order to analyse the entire period that a company has spent in bankruptcy, we used the dating methodology presented in Figure 1.

Figure 1 | Dating Methodology

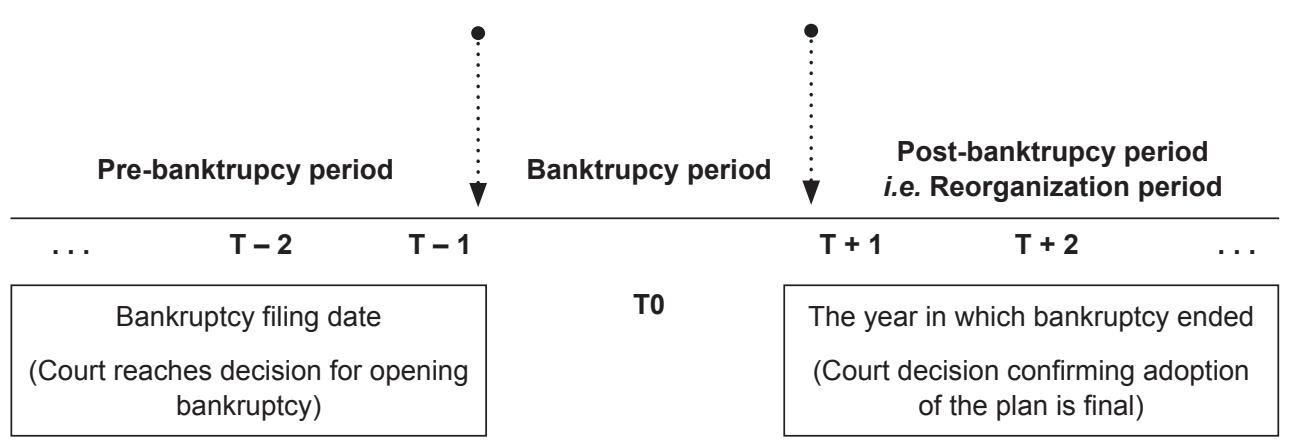

Table 2 | Time Series of Bankruptcy Filings and Recoveries

\begin{tabular}{|l|c|c|}
\hline Year & $\begin{array}{c}\text { Companies entering } \\
\text { bankruptcy }\end{array}$ & $\begin{array}{c}\text { Companies exiting } \\
\text { bankruptcy }\end{array}$ \\
\hline $\mathbf{2 0 0 9}$ & 1 & - \\
\hline $\mathbf{2 0 1 0}$ & 10 & 3 \\
\hline $\mathbf{2 0 1 1}$ & 16 & 14 \\
\hline $\mathbf{2 0 1 2}$ & 15 & 9 \\
\hline $\mathbf{2 0 1 3}$ & 25 & 22 \\
\hline $\mathbf{2 0 1 4}$ & 17 & 28 \\
\hline $\mathbf{2 0 1 5}$ & 2 & 10 \\
\hline Total & 86 & 86 \\
\hline
\end{tabular}


Period T0 denotes the year in which the company filed a bankruptcy petition and the court reached the decision to open bankruptcy, and it lasts until the company's creditors confirm the reorganisation plan and the court's decision verifying the adoption of the reorganisation plan is final. Period $\mathrm{T}+1$ represents the whole first year of the post-bankruptcy performance.

The majority of companies from the final sample entered and exited bankruptcy between 2012 and 2014. Bankruptcy filings were most common in 2013, while most recoveries occurred in 2014. The time distribution of companies entering and exiting bankruptcy is presented in Table 2.

\subsection{Model specification and hypotheses development}

In order to test the relationship between top management turnover, a company's performance and corporate governance mechanisms, we used following specification of the research model:

Top management turnover $=\mathrm{f}$ (financial performance; ownership concentration; applied bankruptcy proceedings; debt monitoring).

The main objective of this paper is to test the following hypotheses:

H1: Top management turnover in distressed Serbian companies is negatively related to a company's financial performance.

H2: Top management turnover in distressed Serbian companies is positively related to high ownership concentration.

H3: A change in the top management is less likely for distressed Serbian companies that file a bankruptcy petition together with a pre-pack reorganisation plan.

H4: Management turnover is positively related to the appointment of the creditors' committee after the reorganisation plan is adopted, as well as to the greater participation of banks in the committees.

\subsection{Variables}

In the study, we used one dependent variable, four sets of explanatory variables and one control variable.

\section{Dependent variable}

Top management team turnover. For the purposes of this research, the top management team is defined as a set of individuals under the age of 65 who hold the positions of director, director general or chairperson of the supervisory or executive board in the year of the bankruptcy filing. A turnover here refers to any situation when individuals holding any of the aforementioned positions left the distressed company during $\mathrm{T} 0$ or $\mathrm{T}+1$, 
as well as any situation when an individual remained in the company but did not hold a relevant top executive position during the observed period. From the authors' point of view, a change in the top management team during bankruptcy and one year following the adoption of a reorganisation plan was closely linked to financial distress, and the majority of observed management turnovers were probably forced. We investigated only the turnover of top management that was not involved in the company's ownership before the bankruptcy filing. Due to the high ownership concentration and strong influence that some companies' owners have on creditors, the relationship between financial distress and the turnover of managers with ownership interest requires a distinct analysis. Accordingly, we introduced the dependent variable $M N G C H A N G E$, which observed two outcomes: We attributed 1 in the event that the top management team changed during $\mathrm{T} 0$ or $\mathrm{T}+1$ and 0 if no change was made to the top management team during the observed period. Instances in which a top manager passed away were not classified as turnover events.

\section{The first set of independent variables}

Financial performance. Gilson (1989, 1990), Jostarndt and Sautner (2008), Firth et al. (2006) document that the likelihood of top management turnover is higher for companies that have lower profitability. Radjen (2015) identifies a strong negative correlation between the company's liquidity and the probability of top management turnover in the case of distressed Serbian companies. In order to avoid multicollinearity, we limited financial performance measures to several accounting indicators. For measuring company profitability, we used ROA and EBITDA margin. ROA is calculated by dividing a company's annual earnings by average assets; this indicator was also used by Firth et al. (2006) and Eckbo et al. (2012) in similar studies. The EBITDA margin (EBITDAMARGIN) is calculated as a ratio of $E B I T D A$ to sales revenue, whereby EBITDA is defined as the earnings before interest, taxes, depreciation, and amortisation; this indicator was also used by Gilson (1990) and Hotchkiss (1995). As an approximation for a company's liquidity, we used the current ratio (LIQUIDITY); this indicator was used by Radjen (2015). In order to isolate the influence of the decisions made during the bankruptcy period on the turnaround strategies, we have used financial figures stemming from the fiscal year-end prior to bankruptcy filing. LoPucki and Whitford (1993b) and Hotchkiss (1995) applied a similar research methodology. Market-based variables were not used because not all of the companies in our sample were listed on the stock exchange.

\section{The second set of independent variables}

Ownership concentration. Large shareholdings mitigate the Free Rider problem and provide efficient management control in transition economies (Balsmeier and Czarnitzki, 2010; Cerovic et al., 2014; among others). Consequently, we will assume that the probability of top management turnover is positively related to ownership concentration. As a measure of the ownership concentration, we used the average size of the largest equity holder in the bankruptcy filing year. In this regard, our research introduced the variable $\log (M 1)$, 
which represents the logarithm of 1 plus the equity holdings of the first largest proprietor in the bankruptcy filing year. While computing equity holdings of the first largest proprietor, we used cash flow rights instead of voting rights since the information regarding voting rights for a large number of companies in our sample was not publicly available. Bearing in mind that the majority of Serbian companies respect the 'once share - one vote' rule, the aforementioned approach should not have distorted the obtained results. Furthermore, we assumed that the equity holding of the first largest proprietor was constant during the observed periods ( $\mathrm{T} 0$ and $\mathrm{T}+1)$. This assumption could be applied because ownership change occurs infrequently in distressed Serbian companies. The Herfindahl Index, a tool to measure ownership concentration, was not available for the majority of companies in our sample.

\section{The third set of independent variables}

Bankruptcy proceedings. In the case of the Republic of Serbia, there are two sources of ma- nagerial power when a company files a bankruptcy petition together with a prepack reorganisation plan. First, the company's managers have the exclusive right to submit a reorganisation plan in pre-packaged bankruptcy proceedings. Second, the incumbent top managers remain in control of the company's operations during bankruptcy. Therefore, we can expect that top management turnover is less likely to occur in companies that file a bankruptcy petition along with a pre-pack reorganisation plan. In order to investigate the influence of applied bankruptcy proceedings on top management, we introduced the variable PREPACK, which observed two outcomes: 1 if the company filed a bankruptcy petition along with a pre-pack reorganisation plan and 0 if the company submitted a reorganisation plan in regular bankruptcy proceedings.

\section{The fourth set of independent variables}

Debt monitoring. After a company defaults on its debts, creditors gain control over the company's decision-making processes and increase their pressure on the company's management team. Transfer of control to creditors is associated with an increase in top management turnover (Gilson, 1989; Franks et al., 2001). As an indicator of the creditors' influence, we used two variables: CREDITORS BOARD, to which we attributed a dummy variable value of 1 in the event that the creditors' committee or a similar body representing the interests of creditors was appointed after the reorganisation plan had been implemented or 0 if no such body was established; and $B A N K$, representing the percentage of voting rights pertaining to banks in creditors' committees. Note that these two variables are highly correlated to an extent to which they create multicollinearity. In order to solve this issue, we regressed variable BANK on CREDITORS BOARD, and we used in the research predicted values of unstandardised residuals instead of the original variable $B A N K$. The residuals are labelled as BANK(resid). After the transformation, the variables CREDITORS BOARD and $B A N K($ resid) are uncorrelated. Fang et al. (2011) used the same approach in resolving the multicollinearity problem. 


\section{Control variable}

Company's size. As the control variable, we used the company's size. In complex and large bankruptcy cases, the information advantage of the incumbent management is greater, and their retention can improve the post-bankruptcy performance of a distressed company (Evans et al., 2014). Also, larger companies engage high-skilled managers that are difficult to replace, especially in the case of an undeveloped labour market (Eriksson, 2005). As a measure of a company's size, we used the logarithm of the company's total assets $(\log (A T))$. Definitions of the variables used in the research are presented in the Appendix.

In order to test the influence of the observed explanatory variables on the discrete dependent variable, we used binary logistic regression, which is one of the most prominent models used in economic research to analyse top management turnover in financially distressed companies. The logistic regressions were run using SPSS software. The logit model is specified as follows:

$$
\begin{gathered}
\text { MNG CHANGE }(1,0)=\beta 1 \times R O A+\beta 2 \times \text { EBITDAMARGIN }+\beta 3 \times \text { LIQUIDITY } \\
+\beta 4 \times \log (M 1)++\beta 5 \times \text { PREPACK }+\beta 6 \times C R E D I T O R S B O A R D+\beta 7 \times B A N K(\text { resid }) \\
+\beta 8 \times \log (\text { AT })+\varepsilon
\end{gathered}
$$

where $\beta$ are the estimated parameters and $\varepsilon$ represents random error term.

\subsection{Descriptive statistics}

Table 3 reports descriptive statistics for the selected variables from the final sample of 86 distressed Serbian companies in the T0 period. The median company from our sample had total assets of EUR 20.99 million, while a standard deviation of 24.76 indicates that data from the sample were spread over a wide range of values (i.e. high assets volatility). The financial ratios $R O A, E B I T D A$ margin and the current ratio confirm that companies from our sample experienced financial distress before they filed for bankruptcy. Statistics presented in Table 3 also indicate that companies from the final sample had a high ownership concentration as a result of the poor protection of minority shareholders and an undeveloped capital market. The ownership concentration was at a high level during $\mathrm{T} 0$ and $\mathrm{T}+1$, with the average equity holdings of the largest owner standing at approximately $75 \%$.

Table 3 | Descriptive Statistics

\begin{tabular}{|l|c|c|c|c|c|}
\hline & N & Minimum & Maximum & Mean & Std. Deviation \\
\hline Assets (in mio EUR) & 86 & 1.16 & 178.15 & 20.99 & 24.76 \\
\hline ROA & 86 & -0.68 & 0.08 & -0.13 & 0.14 \\
\hline EBITDAMARGIN & 86 & -69.96 & 7.33 & -1.26 & 7.71 \\
\hline LIQUIDITY & 86 & 0.13 & 2.00 & 0.75 & 0.37 \\
\hline M1 & 86 & 0.14 & 1.00 & 0.74 & 0.27 \\
\hline
\end{tabular}




\section{Results and Discussion}

\subsection{Results of the logit models}

In the research we defined three types of logit models. In the first model we tested the influence of financial performance on top management turnover. In this respect, we used ROA, EBITDAMARGIN and LIQUIDITY as the explanatory variables. In the second model we analysed the influence of corporate governance mechanisms on top management turnover, and we used $\log (M 1)$, PREPACK, BANK(resid) and CREDITORS BOARD as explanatory variables. In order to test the mutual influence of financial performance and corporate governance mechanisms on top management turnover, we defined the third logit model, in which we used the following explanatory variables: ROA, EBITDAMARGIN, LIQUIDITY, Log(M1), PREPACK, BANK(resid) and CREDITORS BOARD. All three models were extended by the previously defined control variable $\log (A T)$. The number of explanatory variables used in the third model is reconciled with the rule established by Peduzzi et al. (1996). The control and explanatory variables were included in our models by applying the 'enter' method, wherein all variables were included in the model at the same time. Table 4 contains the estimation results from logit regression for all three models, while Table 5 shows the explanatory power of all three models.

Table 4 | Results of the Logit Models

\begin{tabular}{|l|c|c|c|c|c|c|}
\hline \multirow{2}{*}{} & \multicolumn{2}{|c|}{ Model 1 } & \multicolumn{2}{c|}{ Model 2 } & \multicolumn{2}{c|}{ Model 3 } \\
\cline { 2 - 7 } & $\boldsymbol{\beta}$ & Sig. & $\boldsymbol{\beta}$ & Sig. & $\boldsymbol{\beta}$ & Sig. \\
\hline ROA & 1.474 & 0.472 & - & - & 0.832 & 0.707 \\
\hline EBITDAMARGIN & 0.031 & 0.670 & - & - & 0.042 & 0.688 \\
\hline LIQUIDITY & -1.127 & 0.132 & - & - & -0.972 & 0.219 \\
\hline Log(AT) & 0.886 & 0.115 & 1.278 & 0.066 & 1.189 & 0.091 \\
\hline Log(M1) & - & - & -5.880 & 0.078 & -5.654 & 0.094 \\
\hline PREPACK & - & - & 0.685 & 0.208 & 0.601 & 0.286 \\
\hline BANK(resid) & - & - & -0.059 & 0.969 & -0.318 & 0.838 \\
\hline CREDITORS BOARD & - & - & - & - & -0.389 & 0.467 \\
\hline
\end{tabular}

The significance of the explanatory variables used in the second and third model, which is presented in Table 4, demonstrates that the ownership concentration and the company's size influence the top management structure at a $10 \%$ significance level, while applied bankruptcy proceedings and debt monitoring are not significant determinants of top management turnover in distressed Serbian companies (at 5\% and 10\% significance levels). It follows that top management turnover is less likely to occur in larger companies and those with higher ownership concentration. The results of logit regression in the first and the third 
model show that the company's financial performance is not a significant determinant of top management turnover (at 5\% and 10\% significance levels). The sign of the coefficient of all explanatory variables, except $L E V E R A G E$ and $\log (A T)$ is not consistent with the assumptions made in the research. Finally, Table 4 reports that Hypotheses 1, 3, and 4 do not explain the relationship between financial distress and top management turnover, while Hypothesis 2 partially does so. Based on the Nagelkerke R-squared and the Cox and Snell R-squared, which are presented in Table 5, we confirm that the third model has the highest explanatory power.

Table 5 | Explanatory Power of the Regression Models

\begin{tabular}{|l|c|c|c|}
\hline & Model 1 & Model 2 & Model 3 \\
\hline -2 Log likelihood & 106.673 & 104.017 & 102.056 \\
\hline Cox \& Snell R Square & 0.077 & 0.105 & 0.125 \\
\hline Nagelkerke R Square & 0.105 & 0.143 & 0.170 \\
\hline
\end{tabular}

\subsection{Discussion of the results}

The results obtained in this research differ considerably from those that have been reported for developed and transition economies, which can be explained by the distinct characteristics of the local economic and legal environment, and corporate governance practice. A positive and significant influence of the company's size on top management turnover could be explained by the fact that larger companies have a larger internal labour market and lower costs in replacing incumbent managers, (Furtado and Rozeff, 1987; Gilson, 1989). Concerning the negative and significant influence of the ownership concentration on top management turnover, Serbian companies characterise high ownership concentration and large private benefits of control that major owners extract from companies. As a result, controlling shareholders do not have an interest in changing the top management team; rather, they use them as a cover for the realisation of their personal interests. Consequently, the ownership concentration does not provide efficient management control in the case of distressed Serbian companies. Several factors could explain the insignificant influence of other observed variables. Firstly, low sensitivity of the top management turnover to performance is a result of high ownership concentration and large private benefits of control that major owners extract from companies (Volpin, 2002). Secondly, in developed economies bankruptcy reorganisation serves as an external mechanism of corporate governance. In the case of Serbian companies, after a company defaults on its debts, creditors and bankruptcy administrators gain control over the company and its management. However, these control transfer events are not effective in disciplining the company's managers, due to overall creditors' passivity during bankruptcy proceedings and after the adoption of the reorganization plan, as well as bankruptcy administrators' insufficient knowledge of the company's business and its corporate governance systems. Thirdly, the involvement of creditors, particularly banks, in the creditors' committee after 
the adoption of the reorganisation plan depends on the value of the security interest rather than the operations of the company. If the security interest is low, banks will have little incentive to actively monitor the operations and management of distressed companies. In this situation, debt does not play a complementary monitoring role to equity. Fourthly, the absence of a significant negative association between the company's financial performance and top management turnover demonstrates that the corporate governance mechanisms in the Republic of Serbia are not efficient. Moreover, the accuracy and precision of logit estimates in our research are higher than in the research of Radjen (2015), since we examine the top management turnover in a larger sample of distressed companies and analyse the influence of more explanatory variables. This approach can explain the absence of a significant association between the company's liquidity and top management turnover.

\subsection{Limitations}

Our research encountered four important limitations. First, Durbin Watson statistics indicate the presence of a negative autocorrelation in our model $(d=2.19)$. The source of the autocorrelation could be a misspecification of the functional form of the model. However, we were not able to remove the potential source of the autocorrelation due to the small number of observations and limited access to the data concerning the company's top management structure. Second, despite the fact that large- and medium-sized companies in Serbia are subject to external financial audits, financial reports continue to contain hidden losses. Thus, the ratios calculated in this study may not be fully reliable or accurate. Third, our research does not establish a difference between forced and voluntary management turnover. Forth, the small number of available observations does not allow us to more broadly define the models. However, we have also investigated the influence of other explanatory variables that are most commonly used in this type of research, such as the owner's identity, change in the ownership structure, organisational structure (pyramid and cross-ownership), leverage, employee productivity and bankruptcy time. The aforementioned variables did not have a significant contribution in predicting top management turnover in our sample. In order to be able to test the influence of more explanatory variables on top management turnover, future research will need to have at least 10 observations per individual predictor (Peduzzi et al., 1996). Despite the above-mentioned limitations, our research offers valuable results with respect to the existing corporate governance practice in distressed Serbian companies.

\section{Conclusions}

The research in this paper is focussed on exploring the influence of financial distress on corporate governance mechanisms in distressed Serbian companies with an aim to determine factors that influence top management turnover in these companies. This study demonstrates that financial distress in the majority of privately owned companies that adopted a reorganisation plan in the Republic of Serbia did influence their top management. Out of 86 observed companies, a change in top management occurred in 33 companies. 
The probability of top management turnover appeared to be relatively equal during the bankruptcy year and one year immediately after the adoption of a reorganisation plan. Estimates of the logit regression show that the probability of top management turnover is positively related to the company's size and negatively related to the ownership concentration. The influence of all other observed variables on the top management turnover was deemed to be statistically insignificant.

Overall, our paper provides evidence of the ineffective functioning of internal and external corporate governance mechanisms in distressed Serbian companies. Deficiencies in the institutional and legal environment, together with the passive behaviour of major creditors in the corporate sector, are the main obstacles in imposing changes in the existing corporate governance system. In order to achieve the sustainable corporate performance of distressed companies, banks, as the main creditors of the corporate sector, have to increase monitoring of the company's operations and their management. Change in the banks' behaviour can accelerate legal reforms and improve the existing corporate governance system in the Republic of Serbia. Keeping in mind that banking regulation is usually seen as the remedy to the banks' passivity, the Serbian government has to upgrade the existing legal and regulatory framework for banking supervision and define a precise action plan for the recovery and reduction of the NPL portfolio. The recovery plan is especially important in the case of medium- and large-sized distressed companies whose piecemeal liquidation in bankruptcy or during reorganisation could lead to fire-sale discounts and overall losses at the macro-economic level.

\section{References}

Balsmeier, B., Czarnitzki, D. (2010). Ownership Concentration, Institutional Development and Firm Performance in Central and Eastern Europe. ZEW Discussion Paper No. 10-096. https://doi. org/10.2139/ssrn.1739752.

Cerovic, S., Stanisic, N., Radojevic, T., Radovic, N. (2014). The Impact of Ownership Structure on Corporate Performance in Transitional Economies. Amfiteatru Economic, 17(38), 441-454.

Eckbo, B. E., Thorburn, K. S., Wang, W. (2012). How Costly Is Corporate Bankruptcy for the CEO? Tuck School of Business Working Paper No. 2012-109.

Eriksson, T. (2005). Managerial Pay and Executive Turnover in the Czech and Slovak Republics. The Economics of Transition, 13(4), 659-677. https://doi. org/0.1111/j.0967-0750.2005.00236.x.

Evans, J. H., Luo, S., Nagaraja, N. J. (2014). CEO Turnover, Financial Distress and Contractual Innovations. The Accounting Review, 89(3), 959-990. https://doi.org/10.2308/accr-50688.

Fang, Y, Hasan, I. Marton, K. (2011). Bank Efficiency in South-Eastern Europe. Economics of Transition, 19(3), 495-520. https://doi.org/10.1111/j.1468-0351.2011.00420.x.

Firth, M., Fung, P. M., Rui, O. M. (2006). Firm Performance, Governance Structure, and Top Management Turnover in a Transitional Economy. Journal of Management Studies, 43(6), 1289-1330. https://doi.org/10.1111/j.1467-6486.2006.00621.x.

Franks, J., Mayer, C. (2001). Ownership and Control of German Corporations. Review of Financial Studies, 14(4), 943-977. https://doi.org/10.1093/rfs/14.4.943. 
Franks, J., Mayer, C., Renneboog, L. (2001). Who Disciplines Management in Poorly Performing Firms? Journal of Financial Intermediation, 10(3-4), 209-248. https://doi.org/10.1006/ jfin.2001.0317.

Gilson, S. C. (1989). Management Turnover and Financial Distress. Journal of Financial Economics, 25(2), 241-262. https://doi.org/10.1016/0304-405x(89)90083-4.

(1990). Bankruptcy, Boards, Banks and Blockholders. Journal of Financial Economics, 27(2), 355-387. https://doi.org/10.1016/0304-405x(90)90060-d.

Hotchkiss, E. S. (1995). Postbankruptcy Performance and Management Turnover. The Journal of Finance, 50(1), 3-21. https://doi.org/10.1111/j.1540-6261.1995.tb05165.x

Hu, F., Leung. S. C. M. (2012). Top Management Turnover, Firm Performance and Government Control: Evidence from China's Listed State-Owned Enterprises. The International Journal of Accounting, 47(2), 235-262. https://doi.org/10.1016/j.intacc.2012.03.006.

Jostarndt, P., Sautner, Z. (2008). Financial Distress, Corporate Control and Management Turnover. Journal of Banking and Finance, 32(10), 2188-2204. https://doi.org/10.1016/j. jbankfin.2007.12.040.

LoPucki, L. M., Whitford, W. C. (1993a). Patterns in the Bankruptcy Reorganisation of Large Publicly Held Companies. Carnell Law Review, 78(4), 597-618.

(1993b). Corporate Governance in the Bankruptcy Reorganisations of Large, Publicly Held Companies. University of Pennsylvania Law Review, 141(3), 669-800. https://doi.org/10.2307/3312444.

Peduzzi, P. Concato, J., Kemper, E., Holford, T. R., Feinstein, A. R. (1996). A Simulation Study of the Number of Events per Variable in Logistic Regression Analysis. Journal of Clinical Epidemiology, 49(2), 1373-1379. https://doi.org/10.1016/s0895-4356(96)00236-3.

Radjen, D. (2015). The Analysis of the Effects of Financial Distress on the Top Management in the Republic of Serbia. The European Journal of Applied Economics, 12(1), 19-25. https://doi.org/10.5937/ejae12-7977.

Volpin, P. F. (2002). Governance with Poor Investor Protection: Evidence from Top Executive Turnover in Italy. Journal of Financial Economics, 64(1), 61-90. https://doi.org/10.1016/ s0304-405x(02)00071-5. 


\section{Appendix Variable Definition}

\begin{tabular}{|c|c|}
\hline Variable names & Definitions \\
\hline MNG CHANGE & $\begin{array}{l}\text { a dummy variable with a value of } 1 \text { if top management changes, otherwise, } \\
\text { a value of } 0\end{array}$ \\
\hline$R O A$ & net income divided by average annual total assets \\
\hline EBIT & earnings before interest and taxes \\
\hline EBITDAMARGIN & $\begin{array}{l}\text { the ratio of EBITDA (earnings before interest, taxes, depreciation and } \\
\text { amortisation) to sales revenue }\end{array}$ \\
\hline LIQUIDITY & ratio of current assets to current liabilities \\
\hline $\log (M 1)$ & the log of one plus the equity holdings of the first largest proprietor \\
\hline PREPACK & $\begin{array}{l}\text { a dummy variable with a value of } 1 \text { if the company files a bankruptcy } \\
\text { petition together with a pre-pack reorganisation plan, and } 0 \text { if the company } \\
\text { files a reorganisation plan in regular bankruptcy proceedings }\end{array}$ \\
\hline BANK & the percentage of voting rights pertaining to banks in creditors' committees \\
\hline CREDITORS BOARD & $\begin{array}{l}\text { a dummy variable with a value of } 1 \text { if the creditors' committee, or similar body } \\
\text { representing the interests of creditors, is appointed, otherwise, a value of } 0\end{array}$ \\
\hline $\log (A T)$ & the log of total assets \\
\hline BANK(resid) & unstandardised residuals of the original variable BANK \\
\hline
\end{tabular}

